\title{
ВИЗНАЧЕННЯ МОРФОЛОГІЧНИХ ОСОБЛИВОСТЕЙ ПРИДАТКІВ МАТКИ У РАЗІ ЇХ ПЕРЕКРУТУ В ЕКСПЕРИМЕНТАЛЬНОМУ ДОСЛІДЖЕННІ
}

Коробко Ю. Є., Конопліцький В. С.

\section{ВСТУП}

Перекрут придатків матки (яєчників) надзвичайно розповсюджена патологія в дитячій гінекології на території країн пострадянського простору та в країнах Європейського союзу. Ця проблема є дуже важливою, тому що впливає на репродуктивну функцію жінки, що $є$ тісно пов'язаним із демографічною ситуацією в світі. Перекрути придатків матки становлять $2-17 \%$ від усієї гострої гінекологічної патології в дорослих ${ }^{1}$.

Перекрути придатків матки найчастіше пов'язані із супутньою патологією яєчників (функціональні кісти - 25\%, цистаденоми - 30\%, тератоми $-30 \%$, параоваріальні кісти $-2-3 \%)^{2}$. Також у зоні ризику перебувають пацієнти 3 протяжною брижею придатків матки, аномаліями розвитку маткових труб, гемо- або гідросальпінксом, гідатидами Морганьї, з порушеною перистальтикою кишки, трубною гіпермобільністю, гемодинамічними порушеннями у брижі придатків, пацієнти, які перенесли оперативні втручання на органах малого тазу ${ }^{3}$.

Внаслідок перекруту придатків матки в них відмічаються різкі порушення кровопостачання органу, виникає набряк, крововиливи, некроз ${ }^{4}$. Розрізняють повний (на $360^{\circ}$ та $>$ ) і частковий (< ніж на $\left.360^{\circ}\right)$ перекрут придатків матки. До факторів, що спричиняють ушкодження

${ }^{1}$ Bolli P, Schädelin S, Holland-Cunz S, Zimmermann P. Ovarian torsion in children: Development of a predictive score. Medicine (Baltimore). 2017. Vol. 96, № 43. P. 25927. DOI: 10.1097/MD.0000000000008299

${ }^{2}$ Hayward L. M, Sellheim D, Scholl J, Jensen G, Chesbro S. Reflection on Nancy T. Watts' Division of Physical Therapist and Physical Therapist Assistant Responsibility in Clinical Practice: Future Directions. Physical Therapy. 2019. Vol. 99, № 10. P. 12721277. DOI: 10.1093/ptj/pzz089.

${ }^{3}$ Demir M, Barut M. U, Agar M, Karagecili S, Binici O, Bozkurt M, Yilmaz B, Sik A.B, Yumru A.E. Isolated torsion of a tubal ectopic pregnancy: must be kept in mind. International $J$ of Health Services Research and Policy. 2017. Vol. 2, № 1. P. 10-13. DOI: 10.23884/ijhsrp.2017.2.1.02.

${ }^{4}$ Mutiso S.K, Oindi F.M. Pediatric ovarian torsion in a nine-year-old girl: A twisted tale of pain. Int J Case Rep Images. 2017. Vol. 8, № 5. P. 348-351. DOI: 10.5348/ijcri201761-CR-10800. 
придатків, відносять ішемію, підвищення утворення вільних радикалів, явища запалення, порушення нервової регуляції тонусу судин 5 .

На цей час у лікарів немає чіткої тактики щодо перекруту придатків матки: в яких випадках $\epsilon$ можливість зберігати орган, виконавши деторсію, а в яких потрібно його видаляти. Така ситуація виникає в зв'язку із важкістю оцінки глибини ураження придатку, тому що макроскопічна картина зазвичай є більш складною, ніж гістологічна.

Враховуюче вищеописане, можна стверджувати, що на цей момент у хірургічній практиці є значна кількість випадків, коли є можливість провести органозберігаючі операції у випадках, коли макроскопічно придаток вважається нежиттєздатним ${ }^{6}$.

Зважаючи на наявну невідповідність візуальних ознак та морфологічних змін придатків матки у разі їх перекруту, доцільним напрямом у вивченні цієї проблематики $є$ визначення структури яєчника на різних періодах перекруту та після деторсії органу. Оскільки за своєю будовою придатки матки у білих щурів близькі до будови яєчників людини, можна провести вагомі паралелі між результатами дослідження під час визначення тактики лікування.

\section{1. Модель експерименту}

Для експериментального дослідження було відібрано 48 білих щурів 3 масою 200.0 20.0 гр. Вибір цього виду тварин був пов'язаний із тим, що оваріо-менструальний цикл щурів має найбільше схожих рис із людським. Експеримент проводився на базі віварію відповідно до положень «Европейської Конвенції про захист хребетних тварин, які використовуються для експериментальних та інших наукових цілей», (Страсбург, 1986). Протягом усього експерименту щурів утримували на стандартному раціоні харчування за умов вільного доступу до питної води.

Експериментальна модель полягала в тому, що самиці щура під кетаміновим наркозом із розрахунку 20 мг/кг препарату проводили правобічний перекрут яєчника на $720^{\circ}$ у проєкції яйцеводу з фіксацією органу в заданому положенні зовнішньою кліпсою із індиферентного металу (рис. 1).

Процес створення експериментальної моделі виконувався таким чином: після гоління та обробки розчином антисептику шкіри, тваринам, попередньо введеним у наркоз, виконували нижню

${ }^{5}$ Li C, Wang S, Tao X, Hu Y, Li X, Xiao X. Torsion of normal-sized ovary during late pregnancy: A case report and review of the literature. J Obstet Gynaecol Res. 2018. P. 1-5. DOI 10.1111/jog.13758.

${ }^{6}$ Park J. Y, Her K, Kim B. S, Maeng Yh. A completely isolated intestinal duplication cyst mimicking ovarian cyst torsion in an adult. World J Gastroenterol. 2014. Vol. 20, №2. P. 603-606. DOI 10.3748/wjg.v20.i2.603. 
серединну лапаротомію розрізом довжиною 2,0-2,5 см. В лапаротомну рану виводили правий ріг матки 3 придатками та визначали місце створення перекруту яєчника на рівні яйцеводу (рис. 2).

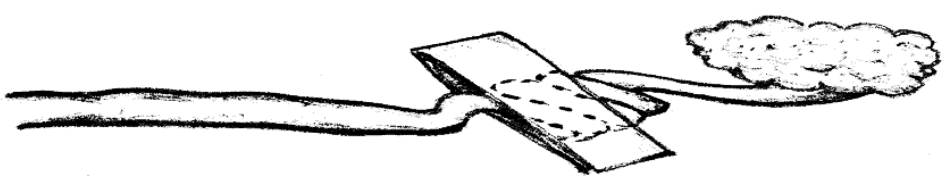

Рис. 1. Експериментальна модель перекруту придатку матки

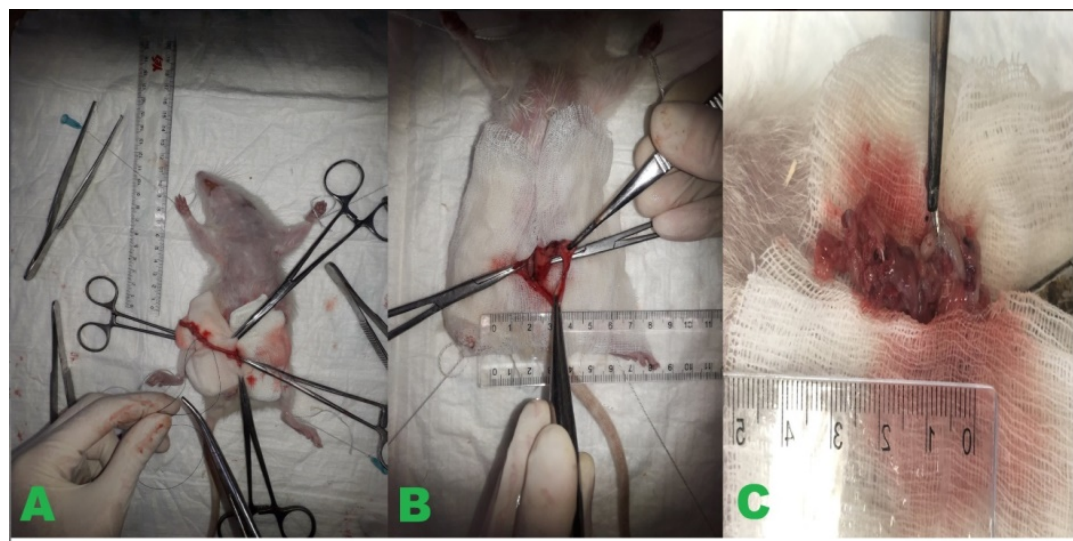

Рис. 2. I етап експерименту: А - виведення в рану правого придатку матки; В - визначення місця перекруту придатку матки; С - фіксація місця перекруту придатку матки металевою кліпсою

На визначеному місці створення патологічного процесу виконували перекрути придатків матки на $720^{\circ}$ відносно їх поздовжньої вісі та фіксували в заданому положенні металевою кліпсою.

Шляхом випадкового відбору тварини були розподілені на чотири групи по шість тварин у кожній: I група - перекрут протягом 24 годин; II група - перекрут протягом 48 годин; III група - перекрут протягом 72 годин; IV група - перекрут протягом 96 годин. Контролем вважались придатки інтактних тварин.

Під час проведення I етапу експерименту у всіх тварин в чотирьох групах у вищенаведені терміни виконували релапаротомію 3 видаленням матеріалу для макроскопічного та морфологічного дослідження. На II етапі експерименту вивчались морфологічні зміни після 24-годинного періоду деторсії ніжки придатків матки різної тривалості (табл. 1). 
Модель проведення експерименту

\begin{tabular}{|c|c|c|c|}
\hline \multicolumn{4}{|c|}{ І етап експерименту. Модель перекруту яєчника. } \\
\hline \multicolumn{4}{|c|}{ Тривалість перекруту яєчника у самиць щурів } \\
\hline № 6 & № 6 & № 6 & № 6 \\
\hline 1 доба & 2 доби & 3 доби & 4 доби \\
\hline \multicolumn{4}{|c|}{ Екстирпація придатків матки для дослідження } \\
\hline \multicolumn{3}{|c|}{ II етап експерименту. Деторсія яєчника після перекруту. } \\
\hline № 6 & № 6 & № 6 & № 6 \\
\hline Через 1 добу & Через 2 доби & Через 3 доби & Через 4 доби \\
\hline Екстирпація придатків матки для дослідження через 1 добу після \\
деторсії \\
\hline \multicolumn{4}{|c}{} \\
\hline
\end{tabular}

На II етапі експерименту, через 1, 2, 3 та 4 доби після створення моделі перекруту придатків матки, у всіх тварин під час релапаротомії усували перекрути шляхом видалення фіксуючої металевої кліпси та деторсії ніжки яєчника. Післяопераційна рана ушивалась наглухо. Ще через 24 години, які відводились на відновлення кровопостачання в яєчнику, у всіх тварин виконувалась повторна релапаротомія, оцінювались візуальні зміни в придатках матки, після чого забирали тканини яєчників для морфологічних досліджень.

Отримані зразки тканин фіксували в $10 \%$ водному розчині нейтрального формаліну протягом двох діб. Після фіксації вилученого інтраопераційно матеріалу його зневоднювали у системі багатоатомних спиртів висхідної концентрації з подальшою заливкою у парафінові блоки. Зрізи препаратів завтовшки 5-7 мкм забарвлювали гематоксиліном та еозином. Вивчення забарвлених мікропрепаратів, їх структурне дослідження 3 фотофіксацією виконували за допомогою морфометричного комплексу Olympus Imaging CORP Model No E - 410 DC 7:4 VD 56547931 за збільшення у 100 та 200 разів.

\section{2. Процес експерименту та обговорення його результатів}

Використовувався стандартний підхід у всіх щурів: у стані наркозу у живих тварин, обов'язково за умов працюючого серця і самостійно функціонуючої системи дихання виконували релапаротомію в терміни, зазначені дизайном I етапу експерименту, проводили огляд та ревізію органів черевної порожнини із візуальною макроскопічною оцінкою змін з боку органів репродуктивної системи. Під час макроскопічного дослідження у тварин через 24 години після створення експериментальної моделі перекруту придатків матки було виявлено повнокрів’я і набряк рогу матки, яйцеводу та яєчника (рис. 3). 


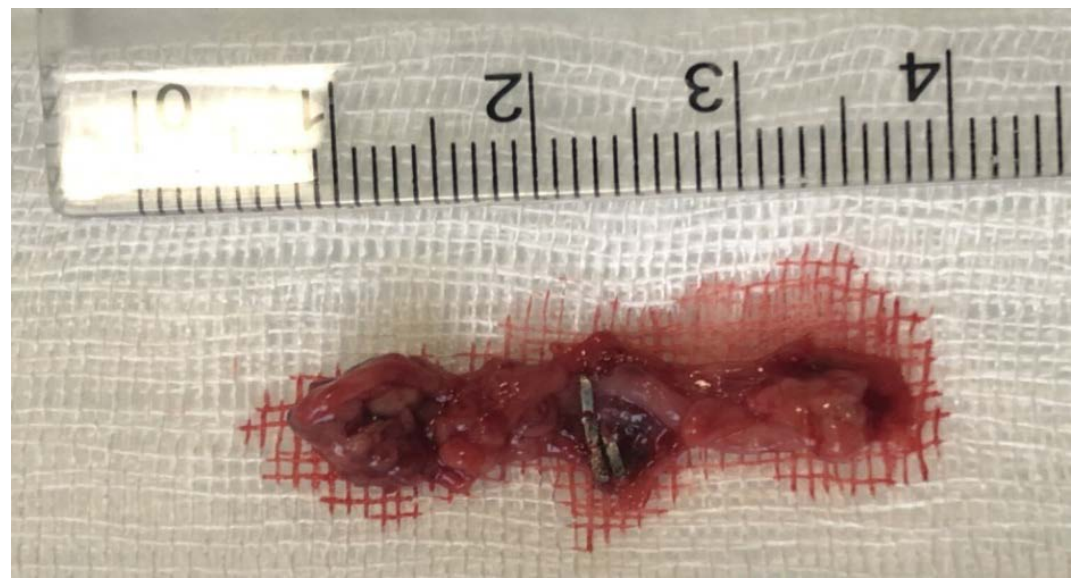

Рис. 3. Макрофото правого придатку матки в термін 24 години після створення моделі перекруту: 1 - набряк правого рогу матки; 2 - помірна гіперемія і набряк яйцеводу та яєчника

Через 48 годин після створення моделі патологічного процесу макроскопічно визначалось збільшення набряку рогу матки, поява поодиноких ділянок венозного стазу в судинах брижі рогу матки, помірна гіперемія та набряк матки (рис. 4).

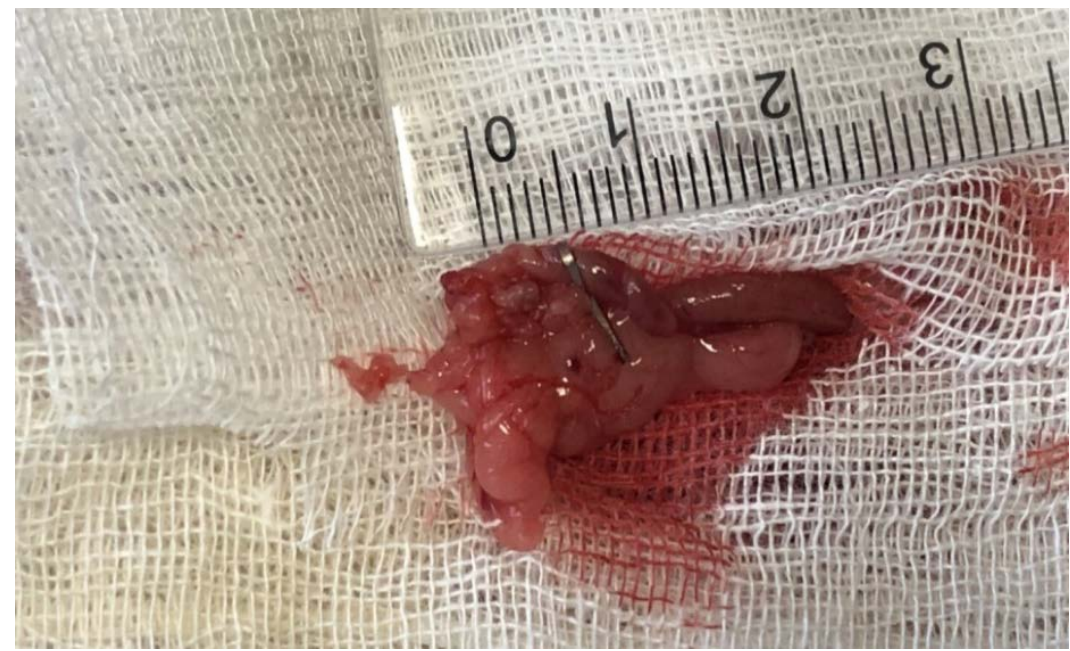

Рис. 4. Макрофото правого придатку матки в термін 48 годин після створення моделі перекруту: поодинокі ділянки венозного стазу в судинах брижі правого рогу матки 
Через 72 години після створення моделі перекруту придатків матки після релапаротомії макроскопічно відмічались виражена гіперемія і набряк яйцеводу, зони крововиливів у яєчнику, множинні ділянки венозного стазу у судинах брижі і рогу матки (рис. 5).
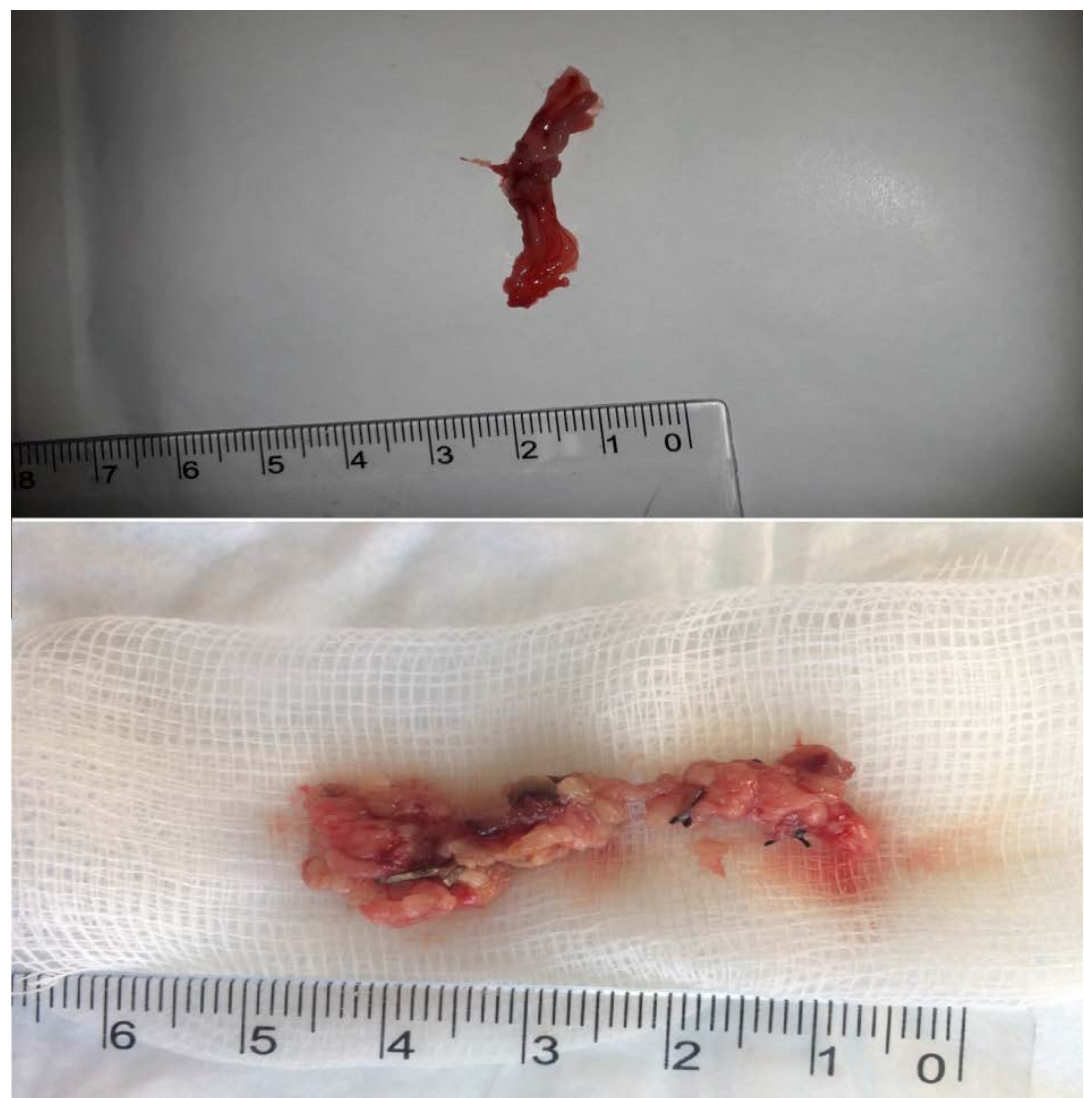

Рис. 5. Макрофото правих придатків матки в термін 72 години після створення моделі перекруту: 1 - виражена гіперемія та набряк яйцеводу; 2 - ділянки крововиливів у яєчник; 3 - венозний стаз у судинах брижі

Через 96 годин після створення перекруту придатків матки в черевній порожнині визначався мутний випіт, множинні зони крововиливів у яєчнику, значні ділянки венозного стазу в судинах рогу матки, значна гіперемія та набряк яйцеводу. Яйцеводи і придатки матки мали багряний колір та важко диференціювались один від одного та від 
оточуючої клітковини в зв'язку із масивним набряком, визначались множинні крововиливи (рис. 6).

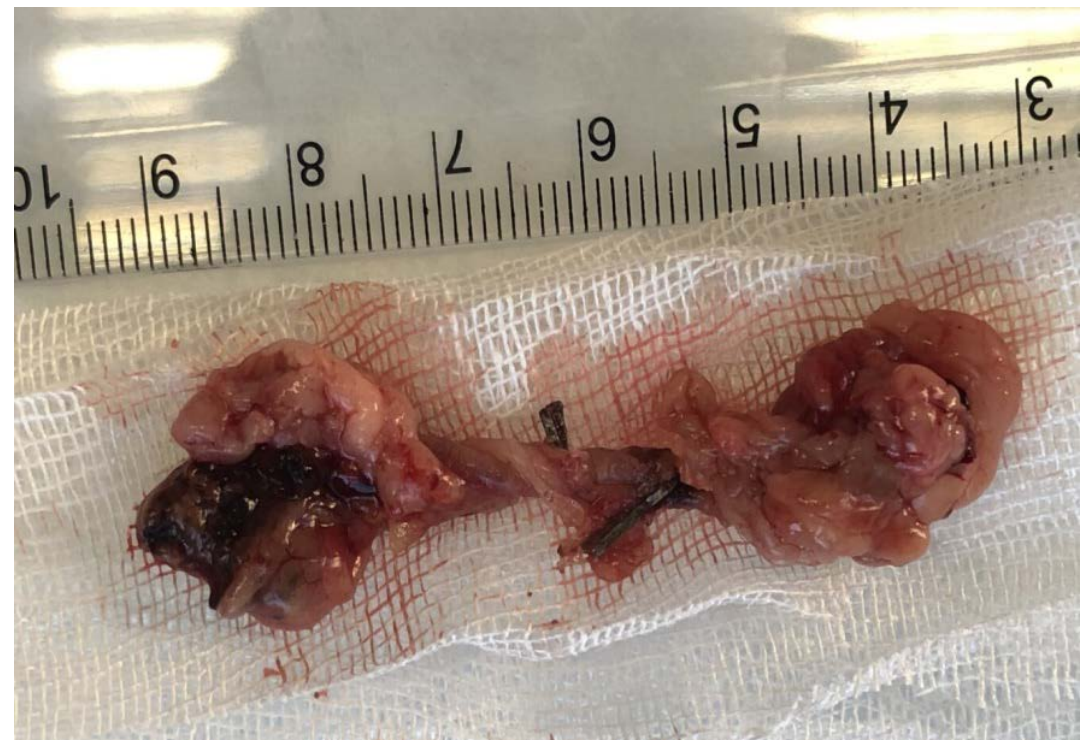

Рис. 6. Макрофото правого придатку матки в термін 96 годин після створення моделі перекруту: 1 - виражена гіперемія та набряк яйцеводу; 2 - масивні крововиливи в ясчник

Комплексна оцінка морфологічних змін у придатках матки експериментальних тварин відбувалась 3 урахуванням трьох основних ознак: некрозу паренхіми яєчників, порушень кровообігу, виразності ознак запалення.

Під час морфологічного дослідження змін у придатках матки експериментальних тварин після їх однодобового перекруту визначались явища помірного повнокров'я судин яєчників та оточуючих тканин. Повнокров'я венозних судин було розповсюдженим, але без деформації судин та дилатації просвіту. В паренхімі та у фолікулах яєчників ділянки некрозу були відсутні. В клітковині на тлі набряку визначалось незначне накопичення перивезикального ексудату, який складався переважно із поодиноких сегментоядерних лейкоцитів та еритроцитів (рис. 7).

На відміну від попередньої групи тварин із одноденним терміном перекруту яєчників, у цей термін характерною була наявність поодиноких перивазальних крововиливів, більш виразна деформація судин внаслідок їх різкого повнокров'я. Ознаки некрозу в цих гістологічних препаратах були відсутні (рис. 8). 


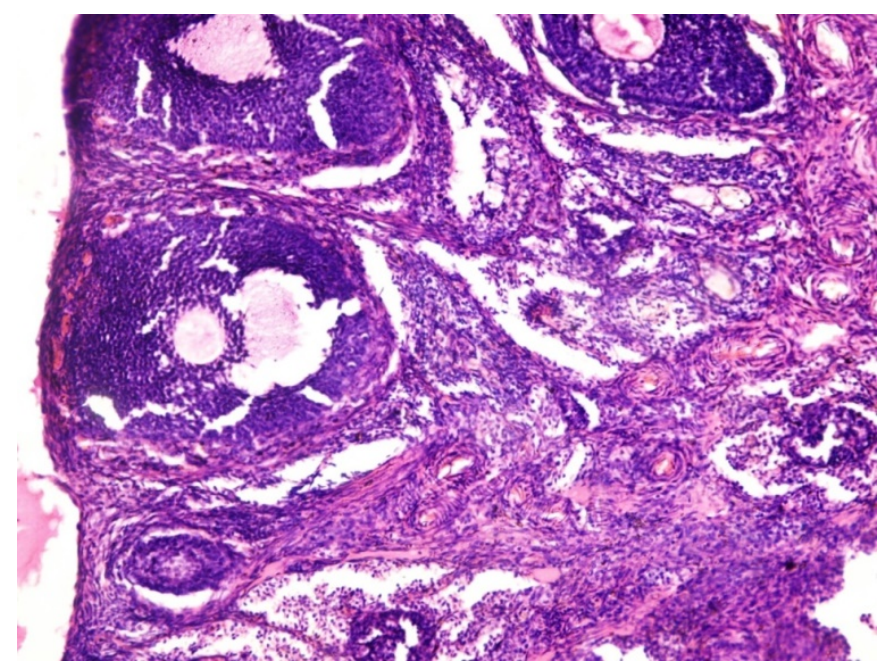

Рис. 7. Зміни в яєчнику щура після однодобового перекруту: 1 - судини мозкового шару ясчника; 2 - третинні фолікули ясчника 3 широким шаром фолікулярних нелютеїнізованих клітин; 3 - первинний фолікул;

4 - вогнищеві крововиливи та набряк у корковому шарі. Забарвлення гематоксилін та еозин. $\times 100$

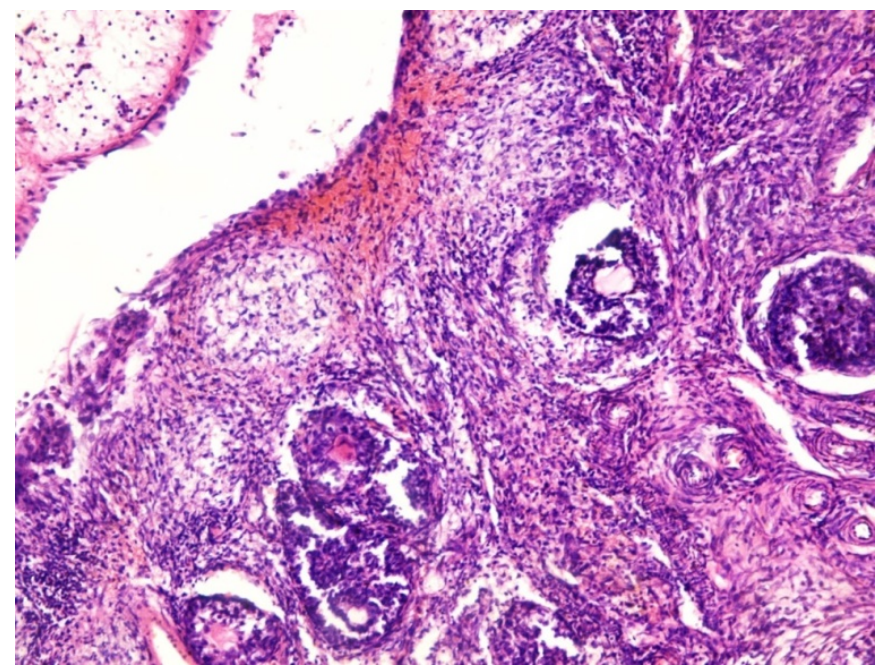

Рис. 8. Зміни в яєчнику щура після дводенного перекруту: 1 - вогнищеві крововиливи, набряк в корковому шарі яєчника; 2 - вторинні фолікули; 3 - оптично порожні судини мозкового шару; 4 - жовті тіла. Забарвлення гематоксилін та еозин. $\times 100$ 
У серії препаратів експериментальних тварин із трьохдобовим перекрутом придатків матки морфологічно визначались ознаки дифузного стійкого порушення кровотоку. Судинна сітка венозного та артеріального русел була звивистою, деформованою та дилятованою. На відміну від попередніх періодів перекруту придатків матки, повнокров'я судин було більше вираженим безпосередньо в паренхімі яєчників. У цей період морфологічно почали визначатись ознаки некрозу в первинних фолікулах. Ознак некрозу у вторинних та третинних фолікулах не спостерігали (рис. 9).

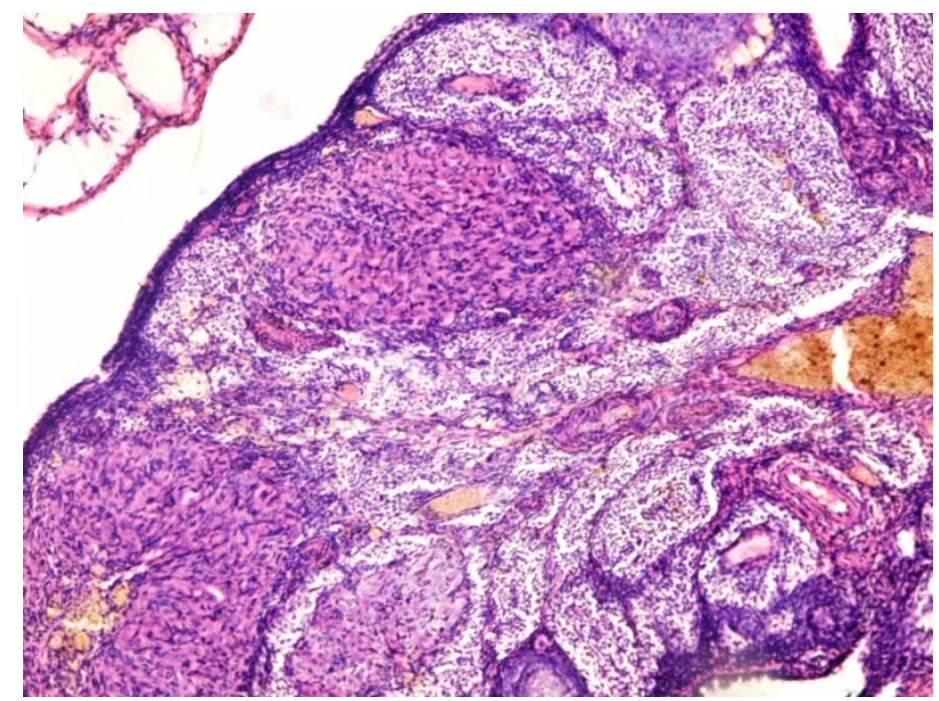

Рис. 9. Зміни в яєчнику щура після трьохденного перекруту:

1 - дилатація та повнокров'я вен мозкового шару; 2 - поля клітин

Сертолі та Лейдіга; 3 - великі жовті тіла 3 крововиливами в них. Забарвлення гематоксилін та еозин. $\times 100$

У гістологічних препаратах експериментальних тварин після чотирьохдобового перекруту придатків матки визначався набряк строми навколо судин яєчників, помірний коагуляційний некроз вогнищевого характеру. Спостерігались помірно виражені вогнищеві дистрофічні зміни у вигляді каріопекнозу та каріорексису в клітинах та їх ядрах, у зонах, що прилягали до ділянок некрозу мозкової речовини. Фолікули не мали структурних змін будови, які б відповідали ознакам некрозу. Більшість судин були дилятованими, визначалось розшарування рівня крові в їх просвітах на рідинний складник та формені елементи. Відмічались ділянки лімфомоноцитарної інфільтрації капсули деяких яєчників (рис. 10). 


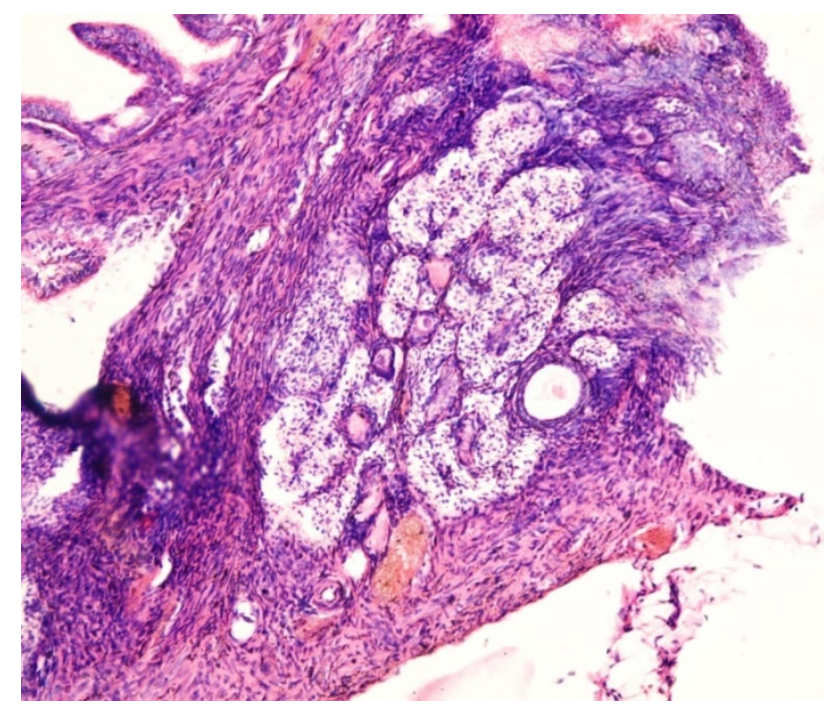

Рис. 10. Зміни в ясчнику щура після чотирьохденного перекруту: 1 - дилатація та повнокров'я вен мозкового шару; 2 - поля клітин Сертолі та Лейдіга; 3 - корковий шар із поодинокими преморбідними фолікулами; 4 - сполучнотканинна строма ясчника; 5 - первинний фолікул. Забарвлення гематоксилін та еозин. $\times 100$

Керуючись результатами дослідження, можна стверджувати, що порушення кровообігу у придатках матки щурів призводить до розвитку патологічних змін у них, інтенсивність яких збільшується пропорційно із тривалістю перекруту. Після усунення перекруту морфологічні зміни в яєчниках не зазнають незворотних некротичних змін та зберігають функціональність. У процесі проведення морфологічних досліджень у разі перекруту придатків матки у самиць щурів 3'ясовано, що граничним терміном збереження гістологічної цілісності гонад були 3 доби.

Дані, що були отримані в експерименті, засвідчили, що присутня невідповідність між макроскопічними ознаками перекручених придатків матки і мікроскопічними змінами при їх морфологічному дослідженні. Попри присутність зовнішніх ознак суттєвих порушень (розвитку ділянок некрозів) у тканині придатків матки, після усунення перекруту спостерігалось відновлення в них кровотоку. Дослідження показали можливість виконання органозберігаючих операцій у разі перекруту придатків матки.

Нами було проведено вивчення особливостей морфологічної будови яєчників у щурів під час перекруту та після деторсії на основі граничного терміну 72 години (табл. 2). 
Таблиця 2

Кількісна оцінка структурних елементів яєчника під час перекруту та через 3 доби після його деторсії

\begin{tabular}{|l|c|c|c|c|}
\hline \multicolumn{1}{|c|}{ Показники } & Контроль & $\begin{array}{c}\text { Під час } \\
\text { перекруту }\end{array}$ & $\begin{array}{c}\text { Після } \\
\text { деторсії }\end{array}$ & $\begin{array}{c}\mathbf{p}_{1} \\
\mathbf{p}_{2}\end{array}$ \\
\hline $\begin{array}{l}\text { Товщина одно- } \\
\text { шарового епітелію, } \\
\text { який покриває } \\
\text { яєчник, мкм }\end{array}$ & $8,22 \pm 0,11$ & $7,84 \pm 0,1$ & $9,68 \pm 0,22$ & $\begin{array}{l}\mathrm{p}_{1}<0,05 \\
\mathrm{p}_{2}<0,05\end{array}$ \\
\hline $\begin{array}{l}\text { Товщина білкової } \\
\text { оболонки яєчника, } \\
\text { мкм }\end{array}$ & $19,18 \pm 0,41$ & $21,16 \pm 0,59$ & $17,24 \pm 0,38$ & $\begin{array}{l}\mathrm{p}_{1}<0,05 \\
\mathrm{p}_{2}<0,05\end{array}$ \\
\hline $\begin{array}{l}\text { Площа поперечного } \\
\text { зрізу яєчника, } \\
\times 10^{3} \text { мкм }\end{array}$ & $9223 \pm 19,38$ & $10368 \pm 22,59$ & $8678 \pm 18,52$ & $\begin{array}{l}\mathrm{p}_{1}<0,01 \\
\mathrm{p}_{2}<0,01\end{array}$ \\
\hline $\begin{array}{l}\text { Площа кіркового } \\
\text { шару, х10 мкмм }\end{array}$ & $8052 \pm 16,32$ & $8324 \pm 17,82$ & $7512 \pm 16,36$ & $\begin{array}{l}\mathrm{p}_{1}<0,01 \\
\mathrm{p}_{2}<0,01\end{array}$ \\
\hline $\begin{array}{l}\text { Товщина кіркового } \\
\text { шару, мкм }\end{array}$ & $1672 \pm 11,06$ & $1734 \pm 12,32$ & $1428 \pm 11,24$ & $\begin{array}{l}\mathrm{p}_{1}<0,05 \\
\mathrm{p}_{2}<0,01\end{array}$ \\
\hline $\begin{array}{l}\text { Площа мозкового } \\
\text { шару, } \times 10^{3} \text { мкм }\end{array}$ & $2564 \pm 13,96$ & $3318 \pm 15,16$ & $2154 \pm 14,22$ & $\begin{array}{l}\mathrm{p}_{1}<0,01 \\
\mathrm{p}_{2}<0,01\end{array}$ \\
\hline $\begin{array}{l}\text { Товщина мозкового } \\
\text { шару, мкм }\end{array}$ & $9058 \pm 4,36$ & $10014 \pm 5,32$ & $8694 \pm 4,64$ & $\begin{array}{l}\mathrm{p}_{1}<0,05 \\
\mathrm{p}_{2}<0,01\end{array}$ \\
\hline $\begin{array}{l}\text { Співвідношення } \\
\text { площі мозкового } \\
\text { шару яєчника до } \\
\text { кіркового }\end{array}$ & $1: 3$ & $1: 4$ & $17,3,5$ & - \\
\hline $\begin{array}{l}\text { Діаметр крово- } \\
\text { носних судин, що } \\
\text { проходять через } \\
\text { мозкову оболонку } \\
\text { яєчника, мкм }\end{array}$ & $12,34 \pm 1,05$ & $8,94 \pm 0,76$ & 1,46 & $\begin{array}{l}\mathrm{p}_{1}<0,05 \\
\mathrm{p}_{2}<0,05\end{array}$ \\
\hline
\end{tabular}

Примітки: $\mathrm{p}_{1}$ - достовірність різниці показників у тварин групи контролю та під час перекруту яєчника; $\mathrm{p}_{2}$ - достовірність різниці показників у тварин в нормі та через 1 добу після деторсії яєчника

Як гістологічні ознаки атрезії фолікулів спостерігали: середню кількість генеративних елементів яєчників, пікнотизацію фолікулярних клітин та текоцитів, відшарування фолікулярних клітин від базальної мембрани, наявність апоптотичних тілець та/або клітинного детриту на периферії антрума, наявність макрофагів у печері фолікула, 
гіпертрофію шару текоцитів. Атретичні фолікули характеризувалися стоншенням зернистого шару клітин.

В усіх термінах перекруту та після деторсії придатків матки у щурів яєчники були вкриті кубічним епітелієм, висота якого була меншою у разі перекруту, ніж у нормі, та більшою після деторсії. Під час перекруту та після деторсії, мікроворсинки на поверхні епітелію були частково редуковані. Білкова оболонка у тварин під час перекруту була товстішою через набряк та розшарування фіброзних волокон в порівнянні з контролем. Після усунення перекруту товщина білкової оболонки була меншою за товщину іiї в контрольній групі тварин.

Відмічалось зменшення діаметру кровоносних судин, що проходять через мозкову речовину яєчника, у разі 3-х добового перекруту в порівнянні з контролем на 27,55\% та збільшення показника на 40,84\% після його реторсії.

На першу добу експерименту у щурів із перекрутом придатків матки у кірковій речовині яєчників містилися фолікули різного ступеня зрілості неправильної форми. На відміну від норми, більша частина фолікулів на цьому етапі експерименту перебувала на початковій та пізній стадії атрезії. Більш виразні явища інволюції визначались у гістологічній структурі та морфометричних показниках вторинних та третинних фолікулів. На 2 та 3 добу перекруту відзначалося прогресування дегенерації фолікулів із заміщенням примордіальних фолікулів сполучною тканиною, про що свідчило їх більш рідке розташування та подекуди розташовування нерівномірними групами. Регрес первинних фолікулів перебігав шляхом утворення атретичних тіл у вигляді зморщеної блискучої оболонки, оточеної текоцитами. Атрезія вторинних та третинних фолікулів відбувалася через стадію атретичного тіла із подальшим заміщенням його інтерстиційними клітинами, а пізніше фіброзною тканиною з ії гіалінозом.

Таким чином, кількість примордіальних фолікулів у яєчнику після 3-х добового перекруту зменшилась на $3,92 \%$ в порівнянні $з$ нормою, а після деторсії збільшилось на 14,96\%. При цьому площа примордіальних фолікулів під час перекруту збільшилась на 9,13\% порівняно з нормою, а після деторсії стала нижче контролю на 5,93\%.

Діаметр примордіальних фолікулів у разі перекруту придатків матки збільшився на 10,72\% в порівнянні з контролем, а після деторсії - на 7,33\% був нижчим за нормальну величину.

В усі терміни перекруту у більшій кількості зріючих фолікулів спостерігались ознаки дегенерації ооцитів - набряк цитоплазми, гіпохромія їх, гомогенізація або вакуолізація цитоплазми, в деяких випадках навіть деструкція клітин, гіпертрофія внутрішньої текальної оболонки, злущування фолікулярних клітин у порожнину, що в 
сукупності свідчило про початкові (на першу добу експерименту) та більш глибокі (на другу та третю добу) процеси атрезії. У частині атретичних фолікулів визначалось повнокров'я судин. Так, кількість атретичних фолікулів у яєчнику під час перекруту складала $6,52 \pm 0,22$,

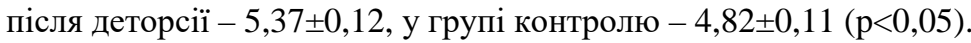

Кількість первинних фолікулів, їх діаметр, площа та кількість фолікулярних клітин у фолікулярному шарі первинного фолікула під час перекруту яєчника зменшилась у порівнянні з контролем, а після деторсії спостерігалось збільшення показників відносно норми.

Кількість вторинних фолікулів у яєчнику та їх площа під час перекруту зменшилась у порівнянні з контролем на 20,69\% і 4,99\%, а після деторсії показники збільшились відповідно на 23,71\% і 9,12\% (p<0,05).

Через I добу після деторсії дегенеративні зміни дозріваючих фолікулів були значно меншими в порівнянні 3 таким у групі із перекрутом гонад: діаметр вторинного фолікула під час перекруту складав 208,16 $\pm 1,22$ мкм, після деторсії - 232,28 \pm 1,14 мкм, у групі контролю - 219,76 \pm 3,92 мкм. Діаметр третинного фолікула під час перекруту гонад в середньому дорівнював 482,46 \pm 5,82 мкм, після деторсії - 545,32 \pm 7,24 мкм, у групі контролю - 509,82 $\pm 6,32$ мкм ( $<<0,05)$.

Кількість третинних фолікулів у яєчнику та їх площа під час перекруту зменшилась у порівнянні з контролем на 33,23\%, 19,9\% відповідно та збільшилась після деторсії на 25,71\% і 6,03\% (p<0,05).

Строма кіркової речовини яєчників між фолікулами та жовтими тілами яєчників була представлена шарами волокнистої фіброзної тканини та інтерстиційними клітинами, що мали веретеноподібну форму. Строма мозкової речовини була представлена оформленою волокнистою фіброзною тканинною.

Площа клітин сполучнотканинної строми коркового шару у нормі в

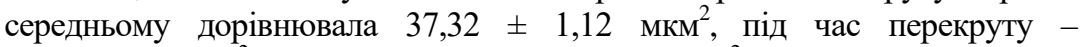
$32,78 \pm 0,74$ мкм², після деторсії - 41,56 $\pm 0,88$ мкм² $^{2}(\mathrm{p}<0,05)$. Площа клітин сполучнотканинної строми мозкового шару в нормі складала 49,33 $\pm 1,42$ мкм² $^{2}$ під час перекруту $-44,16 \pm 0,96$ мкм $^{2}(\mathrm{p}<0,05)$, а після деторсії- 52,62 $\pm 1,86$ мкм $^{2}(\mathrm{p}>0,05)$.

Через I добу після перекруту гонад визначались лейкостази в судинах із виходом поодиноких лейкоцитів за межі судинного русла, на другу - третю добу у яєчниках відмічались вогнища лейкоцитарної інфільтрації мозкової речовини, жовтих тіл, зустрічались поодинокі лейкоцити в кірковій речовині.

\section{ВИСНОВКИ}

Таким чином, під час перекруту гонад відмічались дегенеративнодистрофічні зміни з боку складових елементів судинного русла, а також 
3 боку лютеїноцитів. Паренхіма кіркової та мозкової речовин при перекруті яєчника вже на першу добу характеризувалася пухким розташуванням волокон сполучної тканини. На третю добу експерименту відбувалась більш глибока дезорганізація та потовщення волокнистого компоненту строми. Також у цей термін спостерігались більш значні гемодинамічні зміни у вигляді стазу, паретичного розширення судин, периваскулярного набряку, яке було особливо виразним у мозковій речовині яєчників. Отже, відзначалось прогресування гіпоксії паренхіми яєчника.

Підводячи підсумки, можна вважати доведеним, що перекрут придатків матки у самиць призводить до прискореної та активної атрезії фолікулів, що своєю чергою сприяє зменшенню загальної кількості фолікулів у яєчниках, дегенерації та редукції вмісту лютеоцитів, збільшенню площі строми органу на тлі гемодинамічних порушень, зменшенню розмірів жовтих тіл та їх передчасному регресу, що сприяє поглибленню ушкоджуючого ефекту на всі структури придатків, внаслідок яких виникає зниження репродуктивного потенціалу яєчника.

Після деторсії яєчника в терміни до 72 годин після його перекруту визначається достовірне зворотне відновлення структурних компонентів яєчника як позитивний наслідок впливу деторсії.

Отримані дані довели, що в науково-дослідну практику можна рекомендувати застосування експериментальної моделі перекруту яєчника у щурів для дослідження ефективності впливу та термінів лікувальних факторів на відновлення морфологічних, структурних та функціональних характеристик органу.

\section{АНОТАЦІЯ}

Перекрут придатків матки складає 2-17\% від усієї гострої гінекологічної патології в дорослому віці, або у 4,9 випадках на 100000 пацієнток віком від 1 до 20 років, що складає близько 3\% від загальної кількості гострої гінекологічної патології у дівчат. Отримані в експерименті дані довели присутність невідповідності між макроскопічними та макроскопічними ознаками перекручених придатків матки. Попри присутність зовнішніх ознак суттєвих порушень, після проведення деторсії та відновлення в них кровотоку дослідження показали можливість виконання органозберігаючих оперативних втручань під час перекруту придатків матки. Щодо експериментальних досліджень доведено, що перекрут придатків матки призводить до активної атрезії фолікулів, що своєю чергою сприяє зменшенню розмірів жовтих тіл та їх передчасному регресу, розростанню строми органу на тлі гемодинамічних порушень, дегенерації та редукції вмісту лютеоцитів, що сприяють поглибленню ушкоджуючого ефекту на всі структури придатків матки, 
наслідком чого $\epsilon$ виникнення порушень фолікулогенезу, посилення атретичних процесів, у результаті яких формується зниження репродуктивного потенціалу яєчника. Після деторсії яєчника в терміни до 72 годин після його перекруту визначалось достовірне зворотне відновлення структурних компонентів яєчника як позитивний наслідок впливу деторсії.

\section{ЛIТЕРАТУРА}

1. Bolli P, Schädelin S, Holland-Cunz S, Zimmermann P. Ovarian torsion in children: Development of a predictive score. Medicine (Baltimore). 2017. Vol. 96, № 43. P. 259-27. DOI 10.1097/MD.0000000000008299.

2. Hayward L. M, Sellheim D, Scholl J, Jensen G, Chesbro S. Reflection on Nancy T. Watts' Division of Physical Therapist and Physical Therapist Assistant Responsibility in Clinical Practice: Future Directions. Physical Therapy. 2019. Vol. 99, № 10. P. 1272-1277. DOI 10.1093/ptj/pzz089.

3. Demir M, Barut M.U, Agar M, Karagecili S, Binici O, Bozkurt M, Yilmaz B, Sik A.B, Yumru A.E. Isolated torsion of a tubal ectopic pregnancy: must be kept in mind. International $J$ of Health Services Research and Policy. 2017. Vol. 2, № 1. P. 10-13. DOI 10.23884/ijhsrp.2017.2.1.02.

4. Mutiso S.K, Oindi F.M. Pediatric ovarian torsion in a nine-year-old girl: A twisted tale of pain. Int J Case Rep Images. 2017. Vol. 8, № 5. P. 348-351. DOI 10.5348/ijcri-201761-CR-10800.

5. Li C, Wang S, Tao X, Hu Y, Li X, Xiao X. Torsion of normal-sized ovary during late pregnancy: A case report and review of the literature. J Obstet Gynaecol Res. 2018. P. 1-5. DOI 10.1111/jog.13758.

6. Park J.Y, Her K., Kim B.S, Maeng Yh. A completely isolated intestinal duplication cyst mimicking ovarian cyst torsion in an adult. World $J$ Gastroenterol. 2014. Vol. 20, № 2. P. 603-606. DOI 10.3748/wjg.v20.i2.603.

\section{Information about authors:}

Korobko Yu. Ye., Assistant Lecturer of the Department of Pediatric Surgery

National Pirogov Memorial Medical University

56, Pirogov str., Vinnytsia, 21018, Ukraine

Konoplitskyi V. S., Doctor of Medical Sciences, Professor of the Department of Pediatric Surgery National Pirogov Memorial Medical University 56, Pirogov str., Vinnytsia, 21018, Ukraine 